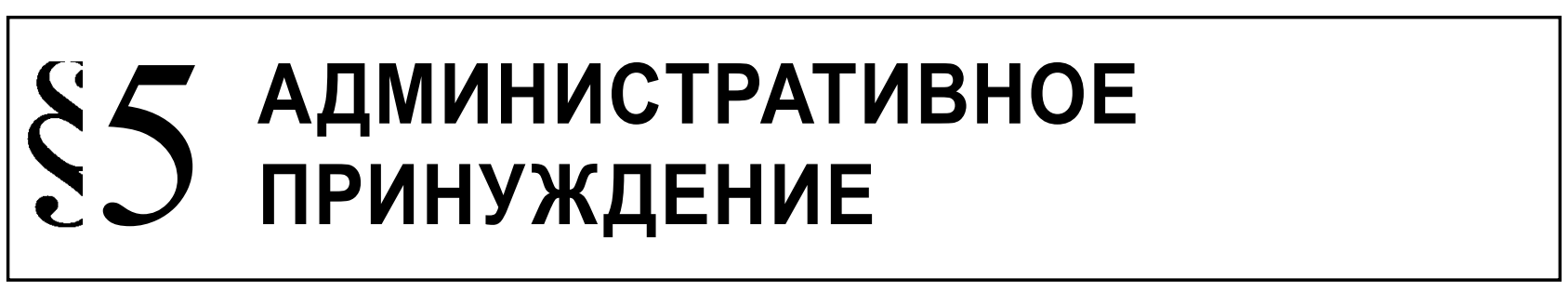

Шубина Е.В.

\title{
АДМИНИСТРАТИВНО-ПРЕДУПРЕДИТЕЛЬНЫЕ МЕРЫ В СИСТЕМЕ АДМИНИСТРАТИВНО-ПРАВОВОГО ПРИНУЖДЕНИЯ
}

\begin{abstract}
Аннотация: Предметом исследования является сущность административно-предупредительных мер административно-правового принуждения, высказаны проблемы связанные с определением такой категории как меры административного предупреждения. В статье также приведены различные точки зрения на такую правовою категорию как административно-правовое принуждение, описаны основные черты административного принуждения, указано место административно-предупредительных мер в системе административно-правового принуждения, обращено внимание на некоторые проблемы применения административно-предупредительных мер, а также предложены пути их решения Диалектико-материалистический метод научного познания, методы социально-правового исследования, а именно сравнительно-правовой, формально-логический,метод контент-анализа. В статье предпринята попытка раскрыть некоторые теоретические и практические проблемы применения мер административно-правового предупреждения, а также предложены пути их решения. Анализ особенностей административно-предупредительных мер в современный период позволит по-новому взглянуть на природу этого явления. Полученные выводы и обобщения будут способствовать развитию административного права, в части, касающейся методов государственного управления и административного процесса. Кроме этого, данная работа может стать основой для более глубоких общетеоретических и отраслевых исследований, в том числе касающихся и профилактической деятельности органов внутренних дел.

Ключевые слова: административное принуждение, меры административного принуждения, меры административно-правового предупреждения, правоохранительная деятельность, административно-процессуальный порядок, исполнительная власть, государственное управление, административно-правовые отношения, государственно-властные полномочия, правонарушение.
\end{abstract}

A дминистративно-правовое принуждение особый вид государственного принуждения, имеющий своим назначением охрану общественных отношений, складывающихся преимущественно в сфере государственного управления. Меры административно-правового принуждения применяются в процессе реализации исполнительной власти соответствующими органами и должностными лицами, что является формой проявления их государственно-властных полномочий.

Сущность административного принуждения раскрывается через основные черты, к которым можно отнести:

- властно-принудительный характер;

- непосредственное фактическое физическое и психическое воздействие на волю и поведение людей;

- содержание этого воздействия выражается в виде ограничений, запретов, дополнительных обязываний личного и имущественного характера, которые обеспечиваются основаниями, порядком и правилами ${ }^{1}$ их реализации;

- административно-правовое принуждение проявляется в различных формах. Это связано с тем, что с помощью данных мер обеспечиваются различные общественные отношения, цели применения административно-правово-

\footnotetext{
Основания - это предусмотренные нормативно-правовыми актами определенные обстоятельства, в связи с которыми появляется необходимость выполнения действий; Порядок - это последовательность действий, а также время, процедура их выполнения;

Правила - это условие, которое необходимо соблюсти, чтобы достигнуть определенного результата;
} 
го принуждения также различны, как и различны основания, содержание полномочий должностных лиц органов исполнительной власти;

- $\quad$ целью применения данных мер является предупреждение правонарушений и наступления иных вредных последствий, пресечение правонарушений, восстановление нарушенного состояния, процессуальное обеспечение и наказание правонарушителя;

- меры административно-правового принуждения устанавливаются законодательством Российской Федерации и осуществляются в соответствии с ним в установленных пределах ${ }^{2}$ и формах;

- административно-правовое принуждение применяется лишь уполномоченными на то органами и должностными лицами. Их круг строго определен правовыми актами;

- административно-правовое принуждение характеризует преимущественно внесудебный порядок его применения соответствующими органами исполнительной власти, должностными лицами в процессе реализации своей компетенции без обращения в суд. Вместе с тем правом административной юрисдикции наделены суды и единолично судьи, которые рассматривают значительную категорию дел об административных правонарушениях и применяют к виновным меры административного наказания, например, за нарушение Правил дорожного движения Р $\Phi^{3}$;

- административно-правовое принуждение осуществляется в рамках особых охранительных административно-правовых отношений, складывающихся в сфере государственного управления и охватывающих права и обязанности компетентных органов и лиц, к которым оно применяется;

- административно-правовое принуждение характеризует и то обстоятельство, что компетентный государственный орган и лица, к которым оно применяется, не связаны отношениями служебной подчиненности, что отличает его от дисциплинарного принуждения, реализуемого в рамках государственно-слу-

2 Пределы - интенсивность, характер, временной период

3 Бровко Н. В., Смоленский М. Б., Соколова Ю. А. Административное право: Учебник для вузов/Н.В. Бровко, М. Б. Смоленский, Ю. А. Соколов. -М.; Ростов-на-Дону:МарТ, 2003. - C. 170. жебных отношений. Административно-правовое принуждение может использоваться в отношении широкого круга субъектов административного права;

- $\quad$ процессуальный порядок его применения отличается оперативностью, относительной простотой и экономичностью;

- административно-правовое принуждение осуществляется в рамках особых охранительных административно-правовых отношений, складывающихся в сфере государственного управления и охватывающих права и обязанности компетентных органов и лиц, к которым оно применяется;

Классификация мер принуждения имеет практическую значимость как для исследования административно-правового принуждения в целом, так и отдельных его видов. На сегодняшний день нет единого мнения о составных элементах системы административно-правового принуждения. Ученые выделяют двух, трех и четырехзвенные классификации. Но классификацией административно-правового принуждения представляющей наиболее значительный научный интерес является классификация, предложенная такими учеными-административистами как А.П. Кореневым, Ю.М. Козловым, Л.Л. Поповым:

- меры административного предупреждения;

- меры административного пресечения;

- меры административно-процессуального обеспечения;

- $\quad$ меры административной ответственности.

Для выявления места и роли мер административного предупреждения в системе административно-правового принуждения необходимо рассмотрение их основных черт и особенностей, а также взглядов ученых на определение данных мер.

Назначение административно-предупредительных мер, как это видно из их названия, прежде всего, состоит в предупреждении возможных правонарушений, а также в предотвращении обстоятельств, представляющих угрозу охраняемым законом интересам; создании необходимых условий для ликвидации последствий таких угроз.

Многие авторы отрицают причастность мер административно-правового предупреждения к принудительным мерам, так как некоторые из их видов лишены принудительного воздействия на волю и сознание людей. Меры подобного рода, несмотря на ярко выраженный профилактический характер, выражающийся как в общей, так и в персонифицированной превенции, осуществляются в 
принудительном порядке, в процессе односторонней реализации юридически-властных полномочий органов исполнительной власти. Ю.М. Козлов в связи с этим считает безосновательными попытки представить их в качестве мер, лишенных элементов административного принуждения ${ }^{4}$. Выражаются они, как правило, в виде определенных ограничений и запретов. Это достаточно убедительно характеризует их принудительный характер. Административно-предупредительные меры не являются следствием совершения правонарушения, наоборот - они направлены на их предотвращение, эти меры предшествуют применению других мер административного принуждения, реализуемых в случаях совершения противоправных деяний. Но, следует отметить и тот факт, что применение, к примеру, мер административного пресечения является предупредительной мерой по отношению к совершению иных, более тяжких нарушений.

Нам импонирует позиция Ю.Н. Старилова, который выделяет следующие характерные черты, присущие административно-предупредительным мерам:

- предупредительные меры не связанны с совершением административного правонарушения, т.е. правонарушение еще не совершено, а принудительные механизмы в отношении соответствующих лиц уже существуют;

- принудительный характер мер рассматриваемой группы состоит в реализации властных и односторонних действий, которые не согласовываются с противоположной стороной (тем не менее, последняя обязана исполнить предписанное ей со стороны уполномоченных органов (должностных лиц), выполнить необходимые в данной ситуации действия либо воздержаться от их совершения);

- административно-предупредительные меры закреплены в законодательных и иных нормативно-правовых актах, предусматривающих обязательные действия либо устанавливающих известные запреты и ограничения под угрозой применения административных санкций за их исполнение. ${ }^{5}$

Обращаясь к исследованию понятия административно-предупредительных мер следует

\footnotetext{
4 Козлов Ю.М. Административное право, - М.: Юристъ, 1999

Старилов Ю.Н. Курс общего административного права. T. 1, - Норма, 2002
}

отметить, что единого общепринятого понятия мер административного предупреждения в отечественном административном праве не существует. Российские ученые-административисты вкладывают различный смыл в их определение. Некоторые авторы включаю в это понятие лишь одну особенность, другие же - несколько.

Взгляды многих отечественных ученых-административистов на определение понятия административно-предупредительных мер расходятся, так как меры административного предупреждения - это сложное административно-правовое явление, которое характеризуются множеством признаков.

Так, к примеру, А.П. Коренев считает, что «... под мерами административного предупреждения понимаются способы и средства, направленные на предупреждение правонарушений и недопущение их отрицательных, вредных последствий, а также на предотвращение наступления обстоятельств, угрожающих жизни и безопасности граждан или нормальной деятельности государственных органов, предприятий, учреждений и организаций» ${ }^{6}$

А, к примеру, Ю.М. Козлов полагает, что «... административно-предупредительные меры применяются в целях предупреждения возможных правонарушений или обеспечения общественной безопасности при стихийных бедствиях и несчастных случаях» ${ }^{7}$.

Меры административного предупреждения закрепляются, в основном, в системе мер административного принуждения. Но, следует отметить, что административно-предупредительные меры имеют как принудительный, так и не принудительный характер.

Разрешению проблемы разграничения предупредительных мер принудительного характера от аналогичных мер не принудительного характера посвящались работы многих ученых-административистов. ${ }^{8}$ В данных работах были обозначены и критерии разграничения обязательности и принудительности к которым относятся воля обязанного субъекта (его отношение к применяемой мере),

\footnotetext{
6 Коренев А.П. Административное право России: Учебник. В трех частях. Часть 1. - М., 1996. - 193 с.

7 Козлов Ю.М. Советское административное право: Пособие для слушателей. - М., 1984. - 151 с.

8 Бахарах Д.Н. Советское законодательство об административной ответственности: Учебное пособие. - Пермь. 1969. - 9-26 c.
} 
характер ограничений, наступающих в связи с применением данной меры. Особое значение имеет отношение обязанного субъекта к применяемой административно - предупредительной мере. Это обусловлено тем, что в юридической литературе имеет место суждение о том, что в таких случаях происходит утверждение воли властвующего вопреки воле подвластного, отрицание воли подвластного и внешнее воздействие на его поведениe. ${ }^{9}$ Но также следует отметить, что волеизъявление властвующего должно иметь обоснование. Другими словами все действия управляющей стороны должны основываться на нормах нормативно-правовых актов, регламентирующих деятельность в данной области.

Правоохранительная деятельность по применению мер административного предупреждения происходит в установленном административно-процессуальном порядке. На сегодняшний день в Российской Федерации существует множество нормативно-правовых актов, закрепляющих процедуру применения различных административно-предупредительных мер, в число которых входят Законы Российской Федерации и ее субъектов, Указы Президента Российской Федерации, Постановления Правительства Российской Федерации, положения, приказы, инструкции, регламенты, а также иные документы. Весьма широкое процессуальное регулирование применения административного предупреждения нельзя признать удобным, так как отсутствует единый нормативно-правовой акт, регламентирующий все аспекты применения предупредительных мер. Также следует отметить, что все нормативно-правовые акты, регламентирующие порядок применения данных мер имеют различную юридическую силу, что, в свою очередь, вызывает некую неоднозначность.

Также хотелось бы отметить то, что на сегодняшний день не существует единого нормативноправового акта, который бы строго определял круг тех органов (должностных лиц), которые уполномочены применять меры административно-правового предупреждения, и регламентировал порядок применения данных мер.

Рассматривая органы исполнительной власти и их должностные лица, нужно сказать, что их полномочия по применению административно-предупредительных мер неодинаковы, что обуславливается их различными задачами, осуществляемыми в сфере государственного управления. Если учитывать данное положение, то можно подразделить данные органы исполнительной власти на два вида, а именно на органы, которые осуществляют функции государственного управления вне связи с совершением правонарушения и органы, которые осуществляют правоохранительную деятельность, связанную с охраной общественного порядка и обеспечением общественной безопасности. Для первой группы право на применение административно-предупредительных мер является дополнением к их основной правосубъектности.

Вторая же группа является главным субъектом применения мер административного предупреждения. Это можно подтвердить положениями ФЗ «0 полиции», в котором сказано, что одним из направлений деятельности полиции является предупреждение и пресечение преступлений и административных правонарушений.

Но также следует отметить, что органы исполнительной власти не являются единственными субъектами, наделенными законодательством Российской Федерации полномочиями на применение административно-предупредительных мер. Данными полномочиями обладают и иные органы государственного управления. Органы исполнительной власти и органы государственного управления являются главными субъектами реализации мер административного предупреждения. Но, в то же время, к числу субъектов применяющих меры административного предупреждения следует и отнести органы местного самоуправления.

Таким образом, подводя итого вышесказанному, следует сделать вывод, что все изложенные признаки мер административно-правового предупреждения определяют их важную роль в системе административного принуждения, но, в то же время, в данном институте имеются некоторые проблемы процессуального применения, которые необходимо устранить для более эффективной деятельности органов исполнительной власти по его реализации.

9 Кожевников С.Н. Государственное принуждение: особенности и содержание // Сов. Государство и право. - 1978. № $5 .-48$ c. 
Административное и муниципальное право $11(83) \cdot 2014$

\section{Библиография:}

1. Конституция Российской Федерации (с учетом поправок, внесенных Законами РФ о поправках к Конституции РФ от 30.12.2008 № 6-ФКЗ, от 30.12.2008 № 7-ФКЗ, от 05.02.2014 № 2-ФКЗ, от 21.07.2014 № 11-ФКЗ)// СПС КонсультантПлюс

2. Федеральный закон от 07.02.2011 № 3-ФЗ (ред. от 21.07.2014) "О полиции"//СПС КонсультантПлюс

3. Бахарах Д.Н. Советское законодательство об административной ответственности: Учебное пособие. - Пермь. 1969

4. Бровко Н.В., Смоленский М. Б., Соколова Ю. А. Административное право: Учебник для вузов / Н.В. Бровко, М. Б. Смоленский, Ю. А. Соколов.-М.; Ростов-на-Дону: МарТ, 2003

5. Кожевников С.Н. Государственное принуждение: особенности и содержание // Сов. Государство и право. - 1978.№ 5.

6. Козлов Ю.М. Административное право,-М.: Юристъ, 1999

7. Козлов Ю.М. Советское административное право: Пособие для слушателей. - М., 1984

8. Коренев А.П. Административное право России: Учебник. В трех частях. Часть 1. - М., 1996

9. Старилов Ю.Н. Курс общего административного права. Т. 1,-Норма, 2002.

\section{References (transliterated):}

1. Konstitutsiya Rossiiskoi Federatsii (s uchetom popravok, vnesennykh Zakonami RF o popravkakh k Konstitutsii RF ot 30.12.2008 № 6-FKZ, ot 30.12.2008 № 7-FKZ, ot 05.02.2014 № 2-FKZ, ot 21.07.2014 № 11-FKZ)// SPS Konsul'tantPlyus

2. Federal'nyi zakon ot 07.02.2011 № 3-FZ (red. ot 21.07.2014) "O politsii"//SPS Konsul'tantPlyus

3. Bakharakh D.N. Sovetskoe zakonodatel'stvo ob administrativnoi otvetstvennosti: Uchebnoe posobie. - Perm'. - 1969

4. Brovko N.V., Smolenskii M. B., Sokolova Yu. A. Administrativnoe pravo: Uchebnik dlya vuzov / N.V. Brovko, M. B. Smolenskii, Yu. A. Sokolov.-M.; Rostov-na-Donu: MarT, 2003

5. Kozhevnikov S.N. Gosudarstvennoe prinuzhdenie: osobennosti i soderzhanie // Sov. Gosudarstvo i pravo. - 1978 .-№ 5.

6. Kozlov Yu.M. Administrativnoe pravo,-M.: Yurist", 1999

7. Kozlov Yu.M. Sovetskoe administrativnoe pravo: Posobie dlya slushatelei. - M., 1984

8. Korenev A.P. Administrativnoe pravo Rossii: Uchebnik. V trekh chastyakh. Chast' 1. - M., 1996

9. Starilov Yu.N. Kurs obshchego administrativnogo prava. T. 1,-Norma, 2002. 